\title{
EFEKTIVITAS PROGRAM BANTUAN LANGSUNG TUNAI PADA MASA PANDEMI COVID-19 DI DESA KAMPUNG BARU KECAMATAN GUNUNG TOAR
}

\author{
Witri Rahayuni ${ }^{1}$, Zaili Rusli ${ }^{2}$ \\ ${ }^{12}$ Fakultas Ilmu Sosial dan Ilmu Politik, Universitas Riau, Indonesia \\ Email : witri.rahayuni4415@student.unri.ac.id, zaili.rusli@ lecturer.unri.ac.id
}

\begin{abstract}
The BLT-Dana Desa is one of the programs issued by the Indonesian government to overcome the impact of the economic factors impacted by the covid-19 pandemic in the form of financial assistance provided to poor families and families affected by the covid-19 pandemic, sourced from the Village Fund revenue budget. The BLT-DD program was deliberately issued by the government in order to overcome the public financial decline as a result of the covid-19 outbreak. This study aims to determine the effectiveness of the BLT-DD program during the covid-19 period in Kampung Baru Village, Gunung Toar District and to find out what are the factors that hinder the effectiveness of the BLT-DD program in its implementation. The theory used in this research is the theory of program effectiveness by Edy Sutrisno by using five indicators to measure program effectiveness (program understanding, right target, on time, goal achievement and real change). To answer these problems, the researcher uses a qualitative approach with a case study method and is descriptive. The results of this study explain that the implementation of the BLT-DD program in Kampung Baru Village has not been effective according to what is used. It is proven by the existence of the Village Government which does not understand its duties in determining the target criteria for the BLT-DD program so that there are still people who have the right to not get BLT-DD. It is hoped that before launching a policy, the government can socialize the program so that the parties concerned understand the purpose of the BLT-DD program.
\end{abstract}

Keywords: Effectiveness; Program; Program Effectiveness; BLT-Village Fund

\section{PENDAHULUAN}

Indonesia mengahadapi insiden khusus berupa corona virus akibat dari virus SARCCov-2 yang menginfeksi korban pertamanya di sebuah kota di Wuhan, China, kemudian menyebar ke seluruh dunia. Pemerintahan Indonesia mengkonfirmasi kasus pertama corona-19 di Indonesia pada 2 Maret 2020, dan membenarkan berbagai spekulasi bahwa corona19 masuk ke Indonesia (Marpaung et al. 2020). Pemerintah RI telah melakukan beberapa kebijakan untuk mengatasi penyebaran virus corona, seperti menghimbau masyarakatnya untuk tetap tidak keluar rumah sampai diberlakukannya pembatasan sosial dalam skala yang besar atau PSBB, meski kebijakan ini membatasi kebebasan berkumpul masyarakat sipil dan pada akhirnya menyebabkan kemerosotan ekonomi dan telah mengambil beberapa langkah nasional (Hadiwardoyo 2020; Ristyawati 2020). Untuk saat ini, PSBB tidak terlalu direkomendasikan untuk melakukan kegiatan bagi penduduk, terutama penduduk yang berdomisili di wilayah pelaksanaan PSBB. Ini membatasi pergerakan warga dan bahkan melarang mereka pulang kampung. Meski banyak kegiatan yang tampak melanggar aturan
PSBB yang didasarkan pada pemerintah Indonesia dan WNI, tim peneliti menemukan bahwa penjelasan diatas didasari oleh urgensi faktor ekonomi dan kecemasan terhadap kebebasan warga untuk berkumpul serta berwisata dan berpikir mempercepat poliferasi adalah sebuah tantangan.

Pembatasan sosial berskala besar (PSBB) merupakan bagian dari Tanggap Darurat Kesehatan Masyarakat yang bertujuan untuk mencegah penyebaran penyakit saat ini antar masyarakat di suatu daerah tertentu. Pemerintah Indonesia dalam menetapkan PSBB berua "peliburan sekolah dan tempat kerja serta pembatasan kegiatan keagamaan", namun tetap memperhatikan kebutuhan pendidikan, roduktivitas kera, dan ibadah masyarakat. Sebagai upaya mengahadau dampak ekonomi tersebut, pemerintah Indonesia telah menyiapkan dana ratusan triliun untuk membantu masyarakat yang terdampak pandemi covid-19, khususnya kalangan menengah kebawah.

Dampak sosial dan ekonomi dari pandemi covid-19 berdampak besar pada kesejahteraan masyarakat. Hal ini mengurangi pertumbuhan 
konomi karena aktivitas ekonomi yang terbatas di tingkat makro yang merupakan penyebab dari banyaknya penduduk kehilangan pekerjaan dan turunnya pertumbuhan ekonomi penduduk sehingga menyebabkan bertambahnya jumlah penduduk miskin. Oleh sebab itu, pemerintah meluncurkan beberapa kebijakan guna mengurangi penularan dan penanggulangan penanggulangan wabah ini. Program yang diperkenalkan oleh pemerintah dibagi menjadi dua kategori, yaitu program non-reguler dan program reguler. Upaya pemerintah saat ini seolah hadir untuk masyarakat dengan beberapa program, antara lain; Program Bantuan Pangan Non Tunai (BPNT), program prakerja, program PKH, program Bantuan Langsung Tunai Kementrian Sosial (BLT KEMENSOS), program Bantuan Langsung Tunai Anggaran Pendapatan Belanja Daerah (BLT APBD), program Bantuan Langsung Tunai Dana Desa (BLT-DD), dan sembako dari APBN dan APBD (Tuwu 2020).

$\begin{array}{cll}\text { Pemerintah } & \text { Indonesia, melalui } \\ \text { Kementerian Desa, } & \text { Pembangunan } & \text { Daerah }\end{array}$ Tertinggal, dan Transmigrasi menerbitkan Permendesa Nomor 6 Tahun 2020 Tentang Perubahan Permendesa Nomor 11 Tahun 2020 yang mengatur tentang prioritas Penggunaan Dana Desa (DD) tahun 2020. Dalam perpu Nomor 11 Tahun 2020 ditegaskan, pengutamaan penggunaan dana desa adalah dapat digunakan antara lain untuk Bantuan Langsung Tunai (BLT) kepada penduduk miskin di desa dan kegiatan penanganan PandemiCorona Virus Disease 2019 (MENTERI DESA, PEMBANGUNAN DAERAH TERTINGGAL dan PERATURAN 2018).

Berdasarkan peraturan Permendes PDTT Nomor 11 Tahun 2020 tersebut, pemerintah membentuk dan menyelenggarakan program untuk mengatasi permasalahan faktor perekonomian masyarakat yang diakibatkan adanya pandemic covid-19 yang dinamakan Program Pendanaan Desa Langsung (BLT-DD). BLT-DD merupakan bantuan keuangan untuk keluarga terdampak pandemi covid-19 (Paat, Pangemanan, dan Singkoh 2021). BLT-DD mempunyai bebebrapa tujuan, yaitu; (1) membantu masyarakat miskin terdampak pandemi covid-19 terhadap sendi-sendi ekonomi dan kesehatan masyarakat agar tetap dapat memenuhi kebutuhan; dan (2) meningkatkan tanggungjawab sosial bersama.
Nilai BLT-DD adalah Rp 600.000 per bulan untuk 3 bulan pertama dan diberikan untuk 3 bulan berikutnya sebesar Rp 300.000 per bulan untuk setiap masyarakat terdampak covid-19 yang memenuhi kriteria sebagai berikut; (1) keluarga miskin atau tidak mampu yang berdomisili di desa bersangkutan; (2) tidak termasuk penerima PKH, Kartu Sembako (BPNT), dan Kartu Prakerja; (3) keluarga yang kehilangan mata pencaharian atau pekerjaan; dan (4) mempunyai anggota keluarga yang rentan sakit menahun/kronis.

Berdasarkan Petunjuk Teknis penyaluran BLT-Dana Desa dalam Peraturan Bupati Kuantan Singingi No 1 Tahun 2020 dengan teknik penghitungan untuk menentukan jumlah penerima BLT-DD mengikuti rumus berikut; (a) bagi desa yang menerima anggaran dana desa kurang dari $\mathrm{Rp} 800.000 .000,-$ mengalokasikan BLT-Dana Desa maksimal 25\% dari jumlah dana desa; (b) bagi desa yang menerima anggaran dana desa $\mathrm{Rp} 800.000 .000$,- sampai dengan $\mathrm{Rp}$ 1.200.000.000,- mengalokasikan BLT-Dana Desa maksimal sebesar $30 \%$ dari jumlah dana desa; (c) bagi desa yang memilki anggaran dana desa lebih dari Rp 1.200.000.000,mengalokasikan BLT-Dana Desa maksimal sebesar 35\% dar total dana desa. Namun, jika kebutuhan desa melebihi maksimal yang dapat dialokasikan oleh desa, maka Kepala Desa dapat mengajukan usulan penambahan alokasi dana desa untuk BLT-Dana Desa kepada Bupati/Walikota. Usulan tersebut harus disertai alasan penambahan alokasi sesuai keputusan Musdesus.

Gunung Toar adalah salah satu dari beberapa kecamatan yang terdapat di kabupaten kuantan singingi di Provinsi Riau. Dimana penduduk Kecamatan Gunung Toar juga merasakan imbas dari pandemi covid-19 dan ikut serta melaksanakan kebijakan baru yang ditetapkan oleh pemerintah mengenai program BLT-Dana Desa. Adapun data penduduk seKecamatan Gunung Toar dapat dilihat pada tabel berikut:

Tabel 1.1 Data Desa Se-Kecamatan Gunung Toar Kabupaten Kuantan Singingi.

\begin{tabular}{llcccc}
\hline N & Nama Desa & Jml & \multicolumn{3}{c}{ Jumlah Penduduk } \\
\cline { 3 - 6 } o & & h & L & P & Jmlh \\
& & Dsn & & & \\
\hline $\mathbf{1}$ & Pulau Rumput & 3 & 359 & 346 & 705 \\
\hline $\mathbf{2}$ & Koto Gunung & 2 & 383 & 342 & 725 \\
\hline $\mathbf{3}$ & Teluk Beringin & 3 & 732 & 739 & 1.471 \\
\hline
\end{tabular}




\begin{tabular}{llllcc}
\hline $\mathbf{4}$ & Pulau Mungkur & 2 & 528 & 505 & 1.033 \\
\hline $\mathbf{5}$ & $\begin{array}{l}\text { Seberang } \\
\text { Gunung }\end{array}$ & 3 & 274 & 305 & 579 \\
\hline $\mathbf{6}$ & $\begin{array}{l}\text { Teberau } \\
\text { Panjang }\end{array}$ & 3 & 619 & 581 & 1.200 \\
\hline $\mathbf{7}$ & Gunung & 2 & 491 & 449 & 940 \\
\hline $\mathbf{8}$ & Toar & 2 & 460 & 461 & 921 \\
\hline $\mathbf{9}$ & Kampung Baru & 3 & 674 & 768 & 1.442 \\
\hline $\mathbf{1 0}$ & Petapahan & 3 & 809 & 733 & 1.542 \\
\hline $\mathbf{1 1}$ & $\begin{array}{l}\text { Lubuk } \\
\text { Terentang }\end{array}$ & 2 & 442 & 463 & 905 \\
\hline $\mathbf{1 2}$ & Siberobah & 3 & 215 & 211 & 426 \\
\hline $\mathbf{1 3}$ & Pisang Berebus & 3 & 446 & 483 & 929 \\
\hline $\mathbf{1 4}$ & $\begin{array}{l}\text { Seberang } \\
\text { Sungai }\end{array}$ & 2 & 669 & 608 & 1.277 \\
\hline & Jumlah & $\mathbf{3 6}$ & $\mathbf{7 . 1 0 1}$ & $\mathbf{6 . 9 9 4}$ & $\mathbf{1 4 . 0 9 5}$ \\
\hline
\end{tabular}

Sumber:Arsip Desa Kampung Baru Tahun 2020

Berdasarkan tabel 1.1 diatas dapat dilihat Kecamatan Gunung Toar mempunyai 14 desa yang definitif sampai akhir tahun 2019, terdapat 36 dusun di Kecamatan Gunung Toar dengan rata-rata 2-3 dusun tiap desa. Jumlah penduduk Kecamatan Gunung Toar pada tahun 2019 berjumlah 14.095, yang terdiri dari 7.101 jiwa laki-laki dan 6.994 jiwa perempuan. Kita bisa melihat presentase penduduk pria dan wanita di setiap desa di kabupaten kuantan singingi, khususnya kecamatan gunung toar.

Desa kampung baru merupakan Ibu Kota dari Kecamatan Gunung Toar dengan jumlah penduduk peringkat ke-3 terbanyak di Kecamatan Gunung Toar dengan luas wilayah $13,24 \mathrm{Km}^{2}$ dan jarak tempuh dari Desa Kampung Baru ke ibu kota kabupaten $10 \mathrm{Km}$ dengan waktu lebih kurang 15 menit. Dimana jumlah penduduk dan jumlah kepala keluarga Desa Kampung Baru dapat kita lihat pada tabel berikut:

Table 1.2 Jumlah Penduduk dan Jumlah Kepala Keluarga Desa Kampung Baru

\begin{tabular}{clcc}
\hline NO & DUSUN & $\begin{array}{c}\text { JUMLAH } \\
\text { PENDUDUK }\end{array}$ & $\begin{array}{c}\text { JUMLAH } \\
\text { KK }\end{array}$ \\
\hline $\mathbf{1}$ & $\begin{array}{l}\text { Dusun } \\
\text { Brawijaya }\end{array}$ & 585 & 175 \\
\hline $\mathbf{2}$ & $\begin{array}{l}\text { Dusun } \\
\text { Bunga } \\
\text { Setangkai }\end{array}$ & 493 & 145 \\
\hline $\mathbf{3}$ & $\begin{array}{l}\text { Dusun } \\
\text { Tanjung } \\
\text { Rangga }\end{array}$ & 364 & 98 \\
\hline & JUMLAH & $\mathbf{1 4 4 2}$ & $\mathbf{4 1 8}$ \\
\hline
\end{tabular}

Sumber: Arsip Desa Kampung Baru 2020
Berdasarkan tabel 1.2 diatas dapat dilihat bahwa penduduk Desa Kampuang Baru pada Dusun Brawijaya terdapat 585 Jiwa, Dusun Bunga Setangkat terdapat 493 Jiwa dan Dusun Tanjung Rangga terdapat 364 Jiwa, sehingga total penduduk Desa Kampung Baru berjumlah 1442 Jiwa dan jumlah Kepala Keluarga di Desa Kampung Baru sebanyak 418 Kepala Keluarga. Jumlah Penduduk tersebut dapat dikatakan sangat padat.

Penyaluran program BLT-Dana Desa kampung baru yang dilaksanakan pada $21 \mathrm{Mei}$ 2020 lalu dengan penyaluran langsung dilakukan tiga tahap penyaluran yaitu tahap 1,2 dan 3 dengan jumlah sebanyak Rp 1.200.000,-. Adapun Data Penerima Bantuan langsung Tunai Dana Desa Kampung Baru dapat diperhatikan pada tabel dibawah:

Tabel 1.3 Data Penerima BLT-DD Kampung Baru

\begin{tabular}{cccc}
\hline No & Tahap & Jumlah & Keterangan \\
\hline $\mathbf{1}$ & Tahap 1 & 36 KK & Terealisasi \\
\hline $\mathbf{2}$ & Tahap 2 & 28 KK & Terealisasi \\
\hline 3 & Tahap 3 & 28 KK & Terealisasi \\
\multicolumn{4}{l}{ Sumber: Arsip Desa Kampung } \\
Baru 2020
\end{tabular}

Dari tabel 1.3 diatas dapat kita lihat jumlah penerima Bantuan Langsung Tunai Dana Desa pada tahap 1 berjumlah 36 Kepala Keluarga, pada tahap 2 dan tahap 3 berjumlah 28 Kepala Keluarga di desa kampuang baru. Ditengah wabah corona 19 seperti sekarang ini, harus diakui bantuan sosial dan perlindungan sosial sangat dibutuhkan. Karena ini bisa menjadi nafas masyarakat yang terkena dampak. Pentingnya efektivitas pelaksanaan program BLT-Dana Desa supaya tidak lagi terjadi cerita negatif tentang kekacauan penyaluran bantuan sosial.

Berdasarkan Permendes PDTT bahwa jumlah yang harus diterima KPM adalah Rp 600.000 setiap bulannya pada 3 bulan pertama, namun dilapangan tepatnya Desa Kampung Baru Kecamatan Gunung Toar mendapat dana BLT tidak sesuai, beberapa KPM dana yang diterimanya dipotong $\mathrm{Rp} 100.000,-$ oleh pemerintahan desa. Pemungutan dana dilakukan pada malam hari, dilakukan oleh kepala desa beserta perangkatnya yang mendatangi rumah beberapa KPM (Hasil wawancara prariset bersama Ibu Nurlela selaku KPM BLT-Dana Desa. Selasa, 17 November 2020). 
Kemudian berdasarkan surat edaran Menteri Desa No. 11 Tahun 2020 yang dikeluarkan oleh Kemendes tentang KPM BLTDana Desa, yaitu; orang miskin, orang miskin yang tidak mendapatkan PKH, BPNT, BLT Pusat dan BLT Daerah. Serta orang miskin yang sesuai indikatornya dari kemensos yaitu mereka yang berpenghasilan dibawah 600 ribu perbulan; mereka yang memiliki penyakit menahun atau kronis; mereka yang terdampak adanya pandemi covid-19, seperti kehilangan pekerjaan dan penghasilan. Lantas, kenapa BPD dan perangkat desa belum bisa masuk dalam masyarakat penerima BLT-Dana Desa, karena tunjangan dari BPD sudah 1 juta keatas sesuai klaster, begitu juga aparat desa yang tunggannya 2 juta. Selain itu, BPD dan perangkat desa tidak terpengaruh penghasilannya karena adanya pandemi ini, karena ada atau tidak adanya covid-19 mereka tetap dibayar, masuk atau tidak masuk kantor mereka juga terus dibayar setiap bulan. Namun di Desa Kampung Baru kecamtan Gunung Toar masih terjadinya ketidaktepatan penyaluran BLT-Dana Desa, dimana dari 26 penerima pada tahap pertama terdapat 4 orang penerima berstatuskan sebagai anggota BPD. Sehingga menimbulkan polemik dikalangan masyarakat (Hasil wawancara Prariset dengan Ibu Nurlela selaku KPM BLT-Dana Desa, Selasa, 17 November 2020).

Berdasarkan penjelasan dan fenomena yang penulis temui, makanya penulis tergiring untuk melaksanakan riset yang terkait dengan Efektivitas Program Bantuan Langsung Tunai Dana Desa (BLT-DD) Saat Wabah Covid-19 di Desa Kampung Baru kecamatan gunung toar kabupaten kuantan singingi.

\section{TINJAUAN PUSTAKA}

\section{Konsep Efektivitas}

Pentingnya efektivitas dalam pelaksanaan suatu program seperti yang kemukakan oleh (Silalahi 2011) dalam bukunya asas-asas manajemen mendefinisikan efektivitas sebagai berikut: "Efektivitas adalah kemampuan untuk memilih tujuan-tujuan atau sasaran-sasaran yang tepat dan mencapainya. Sedangkan (Arif dan Sofyan 2019; Putra 2018) mengemukakan bahwa efektivitas merupakan membandingkan antara tujuan yang telah di rencanakan dan telah ditentukan dengan hasil nyata yang telah diwujudkan. Selanjutnya "Efektivitas merupakan suatu keadaan dimana kemampuan kerja yang dilakukan oleh seseorang atau organisasi untuk mencapai tujuan dan menunjukkan keberhasilan melakukan pekerjaan sesuai dengan apa yang telah direncanakan sebelumnya yang sesuai dengan tujuan yang hendak dicapai oleh suatu program atau organisasi" (Nasila 2014; Shalahuddin, Wiyono, dan Lukitaningsih 2020; Suwito 2014).

Berdasarkan beberapa pendapat di atas mengenai efektivitas, maka penulis menyimpulkan bahwa efektivitas merupakan suatu keadaan dimana kemampuan kinerja seseorang atau organisasi dalam mencapai tujuan dan menunjukkan keberhasilan dalam melakukan kegiatan sesuai dengan apa yang sudah direncanakan sebelumnya. Sesuai tujuan yang hendak dicapai oleh suatu program atau organisasi. Efektivitas yang dimaksudkan dalam penelitian ini adalah tingkat sejauh mana efektivitas program bantuan langsung tunai dana desa kampaung baru. Dimana efektivitas merupakan suatu dimensi tujuan organisasi yang menitikberatkan pada tujuan dan sasaran yang hendak dicapai berdasarkan tujuan yang telah ditetapkan.

\section{Konsep Program}

Menurut Arikunto (1988) dalam bukunya yang berjudul "penilaian program pendidikan, mengemukakan bahwa program merupakan kegiatan yang direncanakan, tentunya perecanaan diarahkan untuk mencapai tujuan. Dengan demikian tujuan dan keberhasilan program dapat diukur. Memang dapat dikatakan tiap orang yang membuat program kegiatan tentu ingin tahu sejauhmana program tersebut dapat terlaksana. Pencapaian tujuan tersebut diukur dengan cara dan alat tertentu. Sedangkan menurut Siagian dalam Westra (1989) mengatakan bahwa program adalah rumusan yang berisi uraian pekerjaan yang akan dilaksanakan beserta petunjuk bagaimana melaksanakannya. Hal ini sependapat dengan Korten dalam Jones (1996) mengemukakan bahwa suatu program adalah kumpulan proyek terkait yang telah dirancang untuk melaksanakan kegiatan yang harmonis dan secara integratif untuk mencapai sasaran kebijaksanaan tersebut secara keseluruhan. Kemudian Jones (1996) mengemukakan bahwa program adalah elemen pertama yang harus ada agar dapat tercipta suatu kegiatan. 
Berdasarkan beberapa definisi program diatas, maka penulis menyimpulkan bahwa program merupakan gambaran dari suatu rencana, dalam hal ini program merupakan bagian dari perencanaan dan sering diartikan bahwa program merupakan kerangka kerja dari dasar pelaksanaan suatu kegiatan. Program yang dimaksud dalam penelitian ini yaitu tentang BLT-DD kampuang baru.

\section{Konsep Efektivitas Program}

Menurut (Ni Wayan 2007) yang menyatakan bahwa dalam mengukur efektivitas suatu program ditentukan dengan beberapa variabel, yaitu:

1. Ketepatan sasaran program

2. Sosialisasi program

3. Tujuan program

4. Pemantauan program.

Menurut (Sutrisno 2007) Efektivitas program adalah sebuah langkah dalam mengukur sampai dimana program berjalan, untuk dapat mencapai tujuan yang diinginkan sebelumnya. Dengan mengidentifikasi hasil studi para ahli mengenai ukuran efektivitas program didalam sebuah organisasi yaitu :

a. Pemahaman program

b. Tepat sasaran

c. Tepat waktu

d. Tercapainya tujuan

e. Perubahan nyata

Menurut Makmur (2015) efektivtas program adalah pelaksanaan sebuah kegiatan yang memperlihatkan ketepatan antara harapan yang diinginkan dengan hasil yang dapat dicapai, sebagaimana ditunjukkan dengan ketepatan harapan, implementasi, dan hasil yang dicapai. Efektivitas program dapat diukur dengan beberapa aspek, yaitu; (1) Ketepatan perhitungan biaya; (2) Ketepatan berpikir; (3) Ketepatan tujuan; (4) Ketepatan sasaran.

Berdasarkan beberapa pernyataan efektivitas program diatas, dapat penulis simpulkan bahwa efektivitas program merupakan sejauhmana realisasi dari sebuah program berdasarkan dengan tujuan yang telah ditetapkan sebelumnya. Dimensi-dimensi diatas merupakan komponen yang mendukung pelaksanaan program sekaligus menentukan keberhasilan dari sebuah program, sebagaimana yang dibahas dalam penelitian ini yaitu efektivitas program BLT-DD pada masa pandemi Covid-19 di desa kampung baru.

\section{METODE PENELITIAN}

Penelitian ini dilakukan dengan menggunakan pendekatan kualitatif. Metode yang digunakan dalam penelitian ini adalah metode studi kasus, dan penelitian ini menganalisis dengan menggunakan sifat deskriptif. Pengumpulan data menggunakan metode wawancara, observasi untuk mengamati secara langsung gejala-gejala yang akan diteliti, dan dokumentasi untuk melihat beberapa data dari leaflet resmi desa kampung baru. Teknik yang digunakan untuk menguji kualitas data adalah teknik triangulasi (triangulate) untuk memastikan apakah proses dan hasil yang diperoleh telah dipahami dengan baik oleh peneliti sesuai dengan yang diinginkan informan.

Penelitian ini bertempat di Desa Kampung Baru Kecamatan Gunung Toar Kabupaten Kuantan Singingi.

\section{HASIL DAN PEMBAHASAN}

Secara lebih jelas pembahasan tentang efektivitas program BLT-DD tersebut dapat dilihat pada pembahasan yang dijabarkan dibawah ini:

\section{(1) Efektivitas Program BLT-DD di Desa Kampung Baru Kecamatan Gunung Toar Kabupaten Kuantan Singingi diukur dengan 5 indikator, yaitu;.}

\section{a. Aspek pemahaman program,}

Yang dimaksud dengan pemahaman program disini adalah bagaimana pemerintah desa dan masyarakat dalam memahami program BLT-DD di Desa Kampung Baru Kecamatan Gunung Toar Provinsi Riau, serta apakah pemerintah desa memahami tugas dan tanggungjawabnya dalam pelayanan kepada masyarakat, sesuai dengan tugas pokok dan fungsinya masing-masing sehingga tujuan dari program BLT-DD ini tercapai dengan semestinya. Dalam aspek ini peneliti melihat dan mengetahui sejauh mana pelaksana program dapat memahami dan memberikan pemahaman kepada masyarakat mengenai program BLT-DD yang dilaksanakan tersebut, sehingga tidak adanya kesalahpahaman dalam program BLTDana Desa. Dengan adanya pemahaman yang 
baik tentang program maka tujuan yang hendak dicapai akan terwujud. Dengan memahami program dengan baik maka segala bentuk rencana akan lebih mudah terorganisir dan lebih mudah diterapkan.

\section{b. Aspek Tepat sasaran,}

Dalam aspek ini dilihat apakah yang dikehendaki tercapai dan menjadi kenyataan. Penentuan sasaran yang tepat baik yang ditetapkan secara indvidu maupun sasaran yang ditetapkan organisasi sesungguhnya sangat menentukan keberhasilan aktivitas organisasi. Demikian pula sebaliknya, jika sasaran yang ditetapkan itu kurang tepat, maka akan menghambat pelaksanaan berbagai kegiatan itu sendiri. Sasaran program BLT-DD yang seharusnya sesuai dengan Pedoman Teknis Penggunaan Dana Desa Kabupaten Kuantan Singingi Tahun 2020; penduduk miskin yang karena dampak bencana non alam pandemi Covid-19 kehilangan mata pencaharian/pekeraan, isolasi di desa yang berdasarkan rekomendasi tim kesehatan dan pemerintahan desa, mempunyai anggota keluarga yang rentan sakit menahun/kronis, dan/atau menurunnya pendapatan yang berakibat kurangnya kemampuan memenuhi kebutuhan pangan.

Aspek ini mencoba mengukur bagaimana kesesuian program BLT-DD terhadap Keluarga Penerima Manfaat (KPM). Hal ini sesuai dengan Peraturan Bupati Kuantan Singingi Nomor 1 Tahun 2020 pasal 21A ayat (5) "yang menerima BLT-Dana Desa merupakan keluarga kehilangan mata pencarian atau pekerjaan, belum terdata menerima Program Keluarga Harapan (PKH), BPNT, dan kartu pra kerja, serta yang mempunyai anggota keluarga yang rentan sakit menahun/kronis". Dengan memperhatikan kelompok sasaran dalam sebuah program maka suatu program dapat dikatakan efektif atau tidak.

\section{c. Aspek tepat waktu,}

Aspek tepat waktu ini dilihat melalui penggunaan waktu untuk pelaksanaan program yang telah direncanakan tersebut apakah telah sesuai dengan yang diharapkan sebelumnya. Ketepatan waktu pada hakikatnya merupakan sesuatu yang dapat menentukan keberhasilan dari pelaksanaan suatu program atau kegiatan. Penggunaan waktu yang tepat akan menciptakan efektivitas pencapaian tujuan yang telah ditetapkan sebelumnya.

Jangka waktu dan besaran pemberian BLTDana Desa yang tertuang dalam Pedoman Teknis Penggunaan Dana Desa Kabupaten Kuantan Singingi Tahun 2020; 1). Masa penyaluran BLTDana Desa 3 (tiga) bulan terhitung sejak April 2020; dan 2). Besaran BLT-Dana Desa per bulan sebesar Rp 600.000,00 (enam ratus ribu rupiah) per keluarga. Ketepatan waktu pencairan Bantuan Langsung Tunai Dana Desa di Desa kampung Baru dilaksanakan 3 periode yaitu di bulan Mei, Juni, Juli. Namun dalam teknis di lapangan pencairannya terkadang tidak tepat waktu, lebih cepat atau lebih lambat. Dengan demikian dalam hal pencairan dana ini, waktunya berubah-ubah sesuai dengan pencairan dana dari pusat. Jadi apabila ada keterlambatan itu terjadi karena memang dari pemerintah pusat yang lambat dalam pencairan dana kepada Pemerintah Desa.

\section{d. Aspek Tercapainya Tujuan,}

Aspek ini diukur melalui pencapaian tujuan kegiatan yang telah dijalankan. Tujuan dari BLTDD sendiri ialah dalam jangka pendek diharapkan dapat mengurangi beban masyarakat yang terdampak pandemi virus covid-19 dan menyebabkannya harus kehilangan pekerjaan, dan dalam jangka panjang diharapkan dapat memutus rantai kemiskinan antar generasi.

BLT-DD mempunyai beberapa tujuan, yaitu; (1) membantu masyarakat miskin terdampak pandemi covid-19 terhadap sendisendi ekonomi dan kesehatan masyarakat agar tetap dapat memenuhi kebutuhan; dan (2) meningkatkan tanggungjawab sosial bersama. Dengan tercapainya tujuan suatu program sebagaimana yang diharapkan pemerintah Indonesia, maka program tersebut sudah bisa dikatakan berhasil dan efektif.

\section{e. Aspek perubahan nyata,}

Dalam aspek ini perubahan mengandung makna beralihnya keadaan sebelumnya menjadi keadaan sesudahnya. Perubahan merupakan hal yang cukup sulit dalam suatu program. Suatu program dapat dikatakan efektif apabila program tersebut dapat berjalan dengan baik serta dapat memberikan hasil yang nyata kepada kelompok sasaran. 
Diukur melalui sejauhmana kegiatan tersebut memberikan suatu efek atau dampak serta perubahan nyata bagi masyarakat ditempat. Indikator pengukuran efektivitas program BLTDana Desa dilihat dari segi perubahan nyata, dimana dengan program BLT-Dana Desa diharapkan mampu memberikan perubahan positif terhadap masyarakat yang terdampak pandemi covid-19. Yang dimaksud perubahan nyata dalam penelitian ini adalah perubahan kondisi yang terjadi di Desa Kampung Baru Kecamatan Gunung Toar Kabupaten Kuantan Singingi Provinsi Riau sebelum dan sesudah adanya program BLT-Dana Desa pada masa pendemi covid-19 ini apakah masyarakat telah menerapkan anjuran pemerintah untuk tetap berada dirumah setelah di keluarkannya program BLT-DD ini atau apakah masyarakat masih tetap berkeliaran diluar rumah untuk melakukan pekerjaannya dalam memenuhi kebutuhan sehari-hari. Dengan adanya perubahan yang nyata sesuai dengan yang diharapkan maka program tersebut sudah dikatakan berhasil dan efektif.

\section{(2) Faktor-faktor penghambat a. Faktor Sosialisasi Program,}

Sosialisasi program merupakan kemampuan pelaksana program dalam melakukan sosialisasi program sehingga informasi tentang pelaksanaan program dapat tersampaikan kepada masyarakat pada umumnya dan sasaran peserta program pada khususnya (Budiani 2007) dikutip dalam (Putra 2018). Tahap terpenting dalam menjalankan suatu program supaya berjalan dengan baik adalah pelaksana program dan objek yang dituju harus mengetahui apa saja kriteria atau syarat dari program tersebut, namun pemerintahan desa selaku ujung tombak dalam pelaksanaan program BLT-Dana Desa tidak dapat memberikan sosialisasi kepada masyarakat tentang program BLT-Dana Desa, hal ini yang menyebabkan masyarakat tidak memahami maksud dan tujuan dari program BLT-Dana Desa, sehingga terhambatnya keefektifan program.

\section{b. Faktor Verifikasi Data;}

Verifikasi adalah pemeriksaan atas kebenaran laporan, pernyataan, dan lain-lain sebagai langkah atau melalui metode empiris. Dalam Permendes PDTT Nomor 11 Tahun 2020, Penetapan data keluarga miskin baru di desa diputuskan bersama dalam Musdesus. Musdesus juga dapat membahas target sasaran dan jenis program bantuan yang diberikan kepada masyarakat agar tidak terjadi tumpang tindih target sasaran program bantuan sosial. Mekanisme pendataan BLT-DD sebagaimana diatur dalam petunjuk teknik permendes PDTT, yaitu; (1) pendataan pertama dilakukan oleh relawan desa lawan covid-19, dan setelah data terkumpul selanjutnya pendataan akan fokus pada lingkup RT/RW dan Desa; (2) kemudian, hasil pendataan sasaran keluarga miskin akan dilakukan musyawarah khusus ini akan membahas agenda tunggal, yaitu validasi dan finalisasi data; (3) setelah dilakukan penandatanganan dokumen hasil pendataan oleh Kepala Desa; (4) hasil verifikasi dokumen tersebut, selanjutnya akan dilaporkan kepada tingkat yang lebih tinggi yaitu Bupati atau Walikota melalui Camat; (5) terakhir, program BLT-Dana desa bisa segera dilaksanakan dalam waktu selambat-lambatnya 5 (lima) hari kerja pertanggal diterima di Kecamatan. Pendataan calon penerima BLT-Dana Desa dilakukan oleh Kepala Desa/Tim Relawan Desa dengan Pendampungan dari Pemda.

Verifikasi data digunakan untuk mengoreksi data dan apabila tidak dilakukannya verifikasi data, hal-hal berikut mungkin saja terjadi; (1) adanya penerima BLT-Dana Desa, tetapi orangnya sudah meninggal dunia; (2) adanya nama penerima tetapi orangnya sudah pindah alamat; dan (3) adanya penerima BLT yang tidak layak menerima. Jika hal tersebut terjadi, maka harus melakukan perbaikan data penerima BLTDana Desa.

\section{c. Faktor Pencairan Dana Dari Pusat Lambat;}

Pencairan dana dari pemerintahan pusat merupakan faktor yang sangat mempengaruhi dalam ketepatan waktu penyaluran BLT-Dana Desa. sebagamana diatur dalam pedoman teknis pelaksanaan program BLT-DD yang diatur dalam peraturan Bupati Kabupaten Kuantan Singingi Tahun 2020 program BLT-DD bisa segera dilaksanakan dalam waktu selambatlambatnya 5 hari kerja pertanggal diterima di kecamatan.

Berdasarkan hasil wawancara peneliti dengan beberapa narasumber pada indikatorindikator ukuran efektivitas di atas, informan 
menyatakan terdapatnya faktor penghambat dalam pelaksanaan program BLT-DD di Desa Kampung Baru Kecamtan Gunung Toar Provinsi Riau ini sering terjadinya keterlambatan penyaluran BLT-Dana Desa karena pemerintah pusat lambat mencairkan dana desa tersebut ke tingkat kabupaten, sehingga pelaksana atau pemerintahan desa menyalurkan BLT-DD tersebut sekali dalam 3 bulannya.

\section{d. Faktor Sikap Pelaksana}

"Sikap pelaksana adalah watak dan karakteristik yang dimiliki oleh pelaksana kebijakan, seperti; komitmen, disiplin, kejujuran, kecerdasan dan sifat demokratis"(Ramdhani dan Ramdhani 2017). Untuk mencapainya efektivitas suatu program dalam sebuah organisasi dapat dimulai dari pemimpin, dimana sebuah organisasi tersebut memiliki gaya kepemimpinan yang partisipatif. "Gaya kepemimpinan partisipatif adalah suatu tindakan dari seorang pemimpin dalam menjalankan organisasi. Gaya kepemimpinan partisipatif yang baik dan tepat seharusnya dapat disesuaikan berdasarkan kebutuhan, situasi dan kondisi yang ada di lingkungannya. Dari segi organisasi, gaya kepemimpinan partisipatif dapat diartikan sebagai kemampuan atau kecerdasan mendorong anggotanya agar bekerja sama dalam melaksanakan kegiatan-kegiatan yang terarah pada tujuan bersama"(Shalahuddin, Wiyono, dan Lukitaningsih 2020).

Berdasarkan Permendes PDTT bahwa jumlah yang harus diterima KPM adalah Rp 600.000 setiap bulannya pada 3 bulan pertama, namun dilapangan tepatnya Desa Kampung Baru Kecamatan Gunung Toar mendapat dana BLT tidak sesuai, ada beberapa KPM dana yang diterimanya dipotong Rp 100.000,- oleh pemerintahan desa. Pemungutan dana dilakukan pada malam hari, dilakukan oleh kepala desa beserta perangkatnya yang mendatangi rumah beberapa KPM (Hasil wawancara prariset bersama Ibu Nurlela selaku KPM BLT-Dana Desa. Selasa, 17 November 2020). Selain itu, BPD dan perangkat desa tidak terpengaruh penghasilannya karena adanya pandemi ini, karena ada atau tidak adanya covid-19 mereka tetap dibayar, masuk atau tidak masuk kantor mereka juga terus dibayar setiap bulan. Namun di Desa Kampung Baru kecamtan Gunung Toar masih terjadinya ketidaktepatan penyaluran BLT-Dana Desa, dimana dari 26 penerima pada tahap pertama terdapat 4 orang penerima berstatuskan sebagai anggota BPD. Sehingga menimbulkan polemik dikalangan masyarakat (Hasil wawancara Prariset dengan Ibu Nurlela selaku KPM BLT-Dana Desa, Selasa, 17 November 2020).

Apabila pelaksana kebijakan memiliki sikap yang baik maka dia diduga bisa menjalankan kebijakan dengan baik dan ramah lingkungan, sebaliknya apabila pelaksana kebijakan memiliki sikap atau cara pandang yang berbeda dengan maksud dan arah dari kebijakan, memungkinkan proses pelaksanaan kebijakan dari program BLTDD tersebut tidak akan efektif dan efisien. Sikap pelaksana akan memberikan dukungan dan hambatan terhadap pelaksanaan kebijakan tergantung dari kesesuaian kompetensi dan sikap dari pelaksana. "Kinerja pelaksana yang baik sangat menentukan keberhasilan sebuah organisasi ataupun suatu program untuk mewujudkan visi, misi dan tujuannya"(Siswanto 2020).

Berdasarkan penelitian yang telah dilakukan, penulis memaparkan analisis dari data yang diperoleh selama penelitian di Desa Kampung Baru Kecamatan Gunung Toar Kabupaten Kuantan Singingi Provinsi Riau. Penulis menggunakan teori menurut (Sutrisno 2007) yang menjelaskan bahwa dalam efektivitas pelaksanaan program terdapat lima hal ukuran efektivitas program didalam sebuah organisasi, yaitu;

\section{a) Pemahaman program}

Ukuran efektivitas program pada aspek pemahaman program berdasarkan hasil wawancara riset dengan beberapa informan dari pemerintah desa dan keluarga penerima manfaat program BLT-DD yang dilaksanakan pada hari Selasa 17 November 2020, terdapat beberapa aparat dari pemerintahan desa tidak memahami program BLT-DD sehingga tidak dapat menjelaskan maksud dan tujuan program BLTDD secara tepat dan benar begitu juga dengan masyarakatnya. Permasalahan pada aspek ini terjadi karena tidak adanya sosialisasi sebelum pelaksanaan program BLT-DD, hal tersebut disampaikan oleh bapak Masril selaku Kepala Desa Kampung Baru pada saat wawancara riset. Beliau menyampaikan tidak adanya sosialisasi sebelum pelaksanaan program tersebut yang dikarenakan waktunya yang terlalu singkat. 


\section{b) Ketepatan Sasaran}

Pada aspek ketepatan sasaran, masih adanya sasaran yang seharusnya menerima tetapi belum mendapatkan program BLT-DD. Terbukti dari data yang penulis dapatkan di lokasi penelitian dimana jumlah kuota Keluarga Penerima Manfaat yang disesuaikan dengan 25\% Jumlah Dana Desa sebanyak 103 Orang, sementara Daftar Penerima yang direalisasian Hanya sebanyak 28 orang. Ini membuktikan bahwa pemerintahan desa tidak benar-benar melakukan validasi data dan verifikasi data KPM sehingga masih adanya masyarakat yang seharusnya mendapatkan BLT-DD ternyata belum mendapatkan bantuan tersebut.

\section{c) Ketepatan Waktu}

Pada aspek ketepatan waktu berdasarkan hasil wawancara dengan beberapa informan dari desa kampung baru kecamatan gunung toar yang penulis lakukan yaitu terjadinya kendala yang disebabkan oleh pemerintah pusat yang sering terlambat dalam pencairan dana ke pemerintahan kabupaten, sehingga pemerintah desa melakukan penyaluran BLT-DD sekali 3 bulan bukannya sekali 1 bulan.

\section{d) Pencapaian Tujuan}

Berdasarkan hasil wawancara penulis dengan beberapa informan untuk pelaksanaan program BLT-DD bersama ddengan pelaksana maupun aparat yang terlibat berusaha untuk mewujudkan pencapaian tujuan program, namun berdasarkan wawancara dengan beberapa informan dari keluarga sasaran mereka menyatakan ada yang sangat terbantu, terbantu saja dan sedikit terbantu dengan adanya program ini dan berdasarkan hasil observasi penulis pada kenyataannya masih ada ditemukan KPM yang seharusnya tidak menerima BLT-DD yang mana mereka tidak merasakan dampak setelah adanya BLT-DD karena memang sebelum adanya BLTDD mereka sudah bisa memenuhi kebutuhannya atau bisa dikatakan mampu dan tidak berhak menerima program BLT-DD berdasarkan kriteria yang sudah ditentukan.

\section{e) Perubahan Nyata}

Didalam aspek perubahan nyata ini pemerintah mengharapkan terjadinya perubahan dimana sebelum masyarakat mendapatkan bantuan ini masih berkeliaran di luar rumah untuk melakukan berbagai pekerjaan untuk dapat memenuhi kebutuhan sehari-hari dan setelah menerima program BLT-DD ini pemerintah berharap masyarakat dapat mematuhi anjuran pemerintah untuk tetap berada di rumah selama masa pandemi covid-19 dalam rangka mencegah penyebaran virus covid-19. Berdasarkan hasil riset peneliti dengan beberapa informan di Desa Kampung Baru dalam aspek perubahan nyata belum berjalan efektif karena masyarakat masih tetap berkelian di luar rumah melakukan pekerjaan seperti biasanya dengan alasan bantuan yang diberikan oleh pemerintah masih kurang dalam memenuhi kebutuhan sehari-hari.

\section{KESIMPULAN}

Efektivitas Program Bantuan Langsung Tunai pada masa pandemi covid-19 di Desa Kampung Baru Kecamatan Gunung Toar sebagaimana dilihat dalam pemaparan yang penulis sampaikan diatas mengenai ukuran efektivitas program yaitu; pemahaman program, tepat sasaran, tepat waktu, tercapainya tujuan dan perubahan nyata dapat disimpulkan belum berjalan dengan efektif.

Terdapat beberapa Faktor penghambat dalam keefektifan Program BLT-DD di Desa Kampung Baru yang perlu diperhatikan yaitu: Faktor Sosialisasi Program, pelaksana program lebih aktif lagi dalam memberikan sosialisasi tentang program BTT-DD kepada sasaran sehingga pelaksana dan sasaran sama-sama mengetahui kriteria dan syarat dar program; Faktor Verifikasi Data, pelaksana program tidak benar-benar melakukan verifiasi data sasaran yang dituju sehingga masih adanya belum tepat sasaran; Faktor Pencairan Dana Dari Pusat Lambat, terjadinya keterlambatan pencariran dana dari pemerintahan pusat untuk mencaikan dana kepada tingkat kabupaten sehingga terjadinya keterlambatan penyaluran dana kepada sasaran; dan Faktor Sikap Pelaksana Program BLT-DD, masih adanya ketidaksesuaian jumlah bantuan yang diterima sasaran dengan jumlah yang seharusnya mereka dapatkan karena adanya faktor dari sikap pelaksana program yang tidak mencerminkan pemimpin yang amanah dan bertanggungjawab sesuai tupoksinya sebagai aparat pelaksana program BLT-DD. 
Pada proses pelaksanaan program seharusnya ada koordinasi yang jelas dan baik dari pemerintahan desa sebagai pihak pelaksana sekaligus penanggungawab dalam program BLTDD ini, agar tidak terjadinya miskomunikasi dan tumpang tindih keluarga sasaran. Jika suatu program dilaksanakan dengan menekankan bahwa pentingnya efektivitas dalam pelaksanaan program, maka program tersebut sudah bisa dikatakan mencapai kesuksesannya.

Untuk mengatasi faktor penghambat yang terjadi dalam pelaksanaan program BLT-DD di Desa Kampung Baru penulis memberikan saran dalam faktor sosialisasi program, agar tercapainya pemahaman sebuah program sebaiknya dilakukan sosialisasi dan memberikan panduan atau petunjuk teknis yang lengkap dan jelas sehingga para pelaksana mengetahui dengan jelas dan tidak meraba-raba dalam melaksanakan program tersebut. Selanjutnya faktor Verifikasi Data Lemah, sebaiknya pemerintahan desa melakukan verifikasi data dalam menentukan keluarga sasaran program BLT-DD tersebut. Verifikasi data terhadap pemilihan sasaran harus benar-benar ditentukan sesuai kriteria program yang telah ditentukan supaya tepat sasaran, tidak pandang buluh dan tidak mudah terprovokasi oleh intimidasi pihak lain, walaupun intimidasi tersebut dari pimpinan, jika langkah yang ditentukan tidak sesuai aturan seharusnya diputuskan secara bersama. Kemudian Faktor Pencairan Dana Dari Pusat Lambat, pemerintah pusat seharusnya mencairkan dana sesuai dengan waktu yang telah ditentukan. Sehingga penyaluran dana program bisa dilaksanakan tepat waktu. Begitu juga Faktor Sikap Pelaksana Program BLT-DD, sebaiknya sikap pelaksana adalah mencerminkan sikap seorang pemimpin, melaksanakan program sesuai dengan petunjuk teknis dan aturan yang telah ditetapkan oleh program sehingga tidak adanya masyarakat yang dirugikan oleh sikap pelaksana yang ingin mengambil keuntungan pribadi.

\section{REFERENSI}

Arif, Dwi Ahmad, dan \& Herminarto Sofyan. 2019. "Efektivitas Program Pembelajaran Sekolah Sub T-TEP Toyota (ToyotaTechnical Education Program) Di SMK Negeri 2 Pengasih.” 1(3): 45-54.

Hadiwardoyo, Wibowo. 2020. "Kerugian Ekonomi Nasional Akibat Pandemi Covid-
19." Baskara Journal of Business and Enterpreneurship 2(2): 83-92.

Marpaung, Enrico W., Luthfi Adrian, Sherina Anjani Putri, dan Nisa Nutul Asror. 2020. "Pandemi Covid-19 Dalam Sudut Pandang Demografi Sosial: Penyebaran, Tantangan, Dampak Sosial-Ekonomi Serta Potensi Solusi." Jurnal UI 1(1)(May): 1-15.

Menteri Desa, Pembangunan Daerah Tertinggal, Dan Transmigrasi Republik Indonesia, Dan Peraturan. 2018. "Peraturan Menteri Desa, Pembangunan Daerah Tertinggal, Dan Transmigrasi Republik Indonesia Nomor 7 Tahun 2020 Tentang Perubahan Kedua Atas Peraturan Menteri Desa, Pembangunan Daerah Tertinggal, Dan Transmigrasi Nomor 11 Tahun 2019 Tentang Prioritas Penggu." Sereal Untuk 51(1): 51.

Nasila, Jans Wilianto. 2014. "Efektivitas Program Daerah Pemberdayaan Masyarakat (PDPM), Studi Tentang Penanggulangan Kemiskinan Di Kelurahan Mamboro Kecamatan Palu Utara Kota Palu." Academica Fisip Untad 06(02): 1253-64.

Ni Wayan, Budiani. 2007. "Efektivitas Program Penanggulangan Pengangguran Karang Taruna 'Eka Taruna Bhakti' Desa Sumerta Kelod Kecamatan Denpasar Timur Kota Denpasar." Jurnal Ekonomi dan Sosial 2: 4957.

Paat, Refendy, Sofia Pangemanan, dan \& Frans Singkoh. 2021. "Implementasi Bantuan Langsung Tunai Dana Desa Tahun 2020 Di Desa Tokin Baru Kecamatan Motoling Timur Kabupaten Minahasa Selatan.” 1(1): 1-11.

Putra, Agung Aldino. 2018. "Efektivitas Pelaksanaan Program Bantuan Sosial Pada Masyarakat Di Kota Palu ( Studi Tentang Kelompok Usaha Bersama )." 6 Nomor 8: 18.

Ramdhani, Abdullah, dan Muhammad Ali Ramdhani. 2017. Konsep Umum Pelaksanaan Kebijakan Publik. Vol. 11; No. 01; 2017; 1 12.

Ristyawati, Aprista. 2020. "Efektifitas Kebijakan Pembatasan Sosial Berskala Besar Dalam Masa Pandemi Corona Virus 2019 oleh 
Pemerintah Sesuai Amanat UUD NRI Tahun 1945." 3(2): 240-49.

Shalahuddin, Gendro Wiyono, dan \& Ambar Lukitaningsih. 2020. "Analisis Impresi Kepemimpinan Partisipatif Dan Kompensasi Terhadap Kinerja Berbasis Kepuasan Kerja Karyawan.” Efisiensi: Kaian Ilmu Administrasi 17(2): 96-109.

Silalahi, Ulbert. 2011. "Asas-Asas Manajemen." In Bandung: Refika Aditama,.

Siswanto. 2020. "Promosi Jabatan Sebagai Strategi Peningkatan Kinerja Karyawan." Efisiensi: Kaian Ilmu Administrasi 17(2): 187-97.

Sutrisno, H. Edy. 2007. "Pengaruh Budaya Organisasi, Stres Kerja Dan Komitmen Terhadap Kinerja Karyawan Cv. Bintang Karya Putra Di Surabaya." EKUITAS (Jurnal Ekonomi dan Keuangan) 14(4): 460.

Suwito, Sugito. 2014. "Efektivitas Program Pemberdayaan.” 1(1).

Tuwu, Darmin. 2020. "Kebijakan Pemerintah Dalam Penanganan Pandemi Covid-19." Journal Publicuho 3(2): 267. 